\author{
Hilkka Hiiop, Eva Tammekivi
}

\title{
A NEWLY CONSERVED PLAFOND PAINTING ENRICHES THE OLD TOWN OF TALLINN
}

An exquisite Baroque ceiling panel has been restored and conserved at Rahukohtu 5 on the Patkul viewing platform in the old Town of Tallinn after more than a decade of being exposed to poor conditions. In 1997, an architectural historical investigation was completed in the building. During the field work, one of the largest glue-bound paintings of the Old Town was discovered on the ceiling panels of the first floor. ${ }^{1}$ The exposed mural was in an unacceptable state in an uninhabited room ${ }^{2}$ until construction work began as late as in 2012.

\section{THE DESCRIPTION AND CHRONOLOGY OF THE MURAL}

The Rahukohtu ceiling mural is an ornamental plafond painting featuring a delicate band ornament interwoven with the acanthus motif. On the basis of the band ornament Krista Kodres has dated the painting to the beginning of the eighteenth century ${ }^{3}$ while the Expert Panel for Artistic Monuments at the National Heritage Board has dated the ceiling

http://dx.doi.org/10.12697/BJAH.2013.6.08

Translation by Margus Tuvikene

1 National Heritage Board Archives (Muinsuskaitseameti arhiiv, henceforth TKVA Archive), s.N.1.662: Tallinn, Rahukohtu 5. Hoonete /A1/A2/ väliuurimise I etapi aruanne - Tallinn 1997; Muinsuskaitseameti arhiiv (National Heritage Board Archives), s. A-6285: Aruanne arheoloogilistest kaevamistest Tallinnas, Rahukohtu tn. 5 (1997. a.) Tallinn 1998.

2 In 1859, according to the reconstruction project by Christoph August Gabler's, a partition wall was erected in the room with the mural, breaking the unity of the mural composition.

3 Krista Kodres, "Ruumimaalingud elamute kaunistajana 16.-18. sajandil", Eesti Kunsti ajalugu 2. 1520-1770, ed. Krista Kodres (Tallinn: Estonian Academy of Arts, 2005), 161. 
to 1730 s-1740s. ${ }^{4}$ The mural appears on a grey background its focal point being a dark red flower surrounded by a black band. The central composition is surrounded by baroque ornamentation in segmental arches. The edges are marbled, seashells are placed to the corners and luxurious vases of flowers further inward. Broad ceiling panels are attached to the crossing beams with forged nails and the artwork is distempered on prime coating.

\section{A BRIEF OVERVIEW OF THE RAHUKOHTU 5 ESTATE OWNERSHIP AND BUILDING HISTORY}

The Rahukohtu 5 building is situated inside the Heritage Conservation Area of the Old Town in Tallinn. The estate next to the Patkul viewing platform consists of five joint buildings. The main building is the largest: it is a two storey house with an L-shaped floor plan and a cellar, all other buildings are set on the western edge of the estate. In 1859, a reconstruction project by Christoph August Gabler commenced and an appendage staircase was added to the centre of the main building, while by the Rahukohtu street, a gatehouse with porte cochère was built. In the past, a medieval house was situated in the northern side of the main building. ${ }^{5}$ The southern section is evidently built after the Great Fire of Toompea in $1684^{6}$ as older structures have survived on the basement level. ${ }^{7}$ The eighteenth century construction and the plafond painting verify that either a substantial reconstruction work was carried out or restoration work took place after the fire. ${ }^{8}$

The estate together with its outhouses was originally a residence for nobility and was owned by the Fersen family for a long time. ${ }^{9}$ One can venture a guess that the plafond painting was also ordered by a Fersen descendant. The main building has kept its present appearance from the time when the owner of the estate Aleksander von Wrede complet-

4 Tallinn Culture and Heritage Department archive (Tallinna Kultuuriväärtuste Ameti arhiiv, TKVA Archive), s.N.1.662

Ibid, 6.

6 TKVA Archive, s.N.9.7000: Rahukohtu tn. 5. Muinsuskaitse eritingimused hoonekompleksi restaureerimiseks eluruumideks, kauplusteks, restoraniks. Tallinn 2011, 5 .

TKVA Archive, s.N.9.2465.A: Tallinn, Rahukohtu t 5. Muinsuskaitse eritingimused. Tallinn 2003, no fixed pagination; TKVA Archive, s.N.9.7000: Rahukohtu tn. 5..., no fixed pagination

TKVA Archive, s.N.2465.A: Tallinn, Rahukohtu t 5..., no fixed pagination. ed a reconstruction project in 1859. Gabler's project split the painted area into two rooms of different sizes with a dividing wall and probably at the same time, the mural was covered with reed mats and then plastered. The ceilings of the new rooms were framed with exuberant Late Classicist dentil cornices. Later the estate was purchased by baron Constantin von Ungern-Sternberg. ${ }^{10}$

\section{THE CONDITION OF THE CEILING PAINTING BEFORE THE CONSERVATION}

In spite of the complex history of reconstructions and negligence, surprisingly the plafond painting on the first floor had survived and was in sound condition. The biggest destructor of the mural but also its preserver was the extensive reconstruction work of 1859 that ruined the compositional unity by introducing a dividing wall and massive dentil cornice but also reed mats that covered the mural saving the sensitive layer of paint. The pigment layer had been pulverised to a large extent before the conservation work started, i.e. the adhesive concentration in paint layer had declined considerably and there was only little adhesion left. In some places, the paint layer did not grip to the panels and came off together with the priming coating, leading to substantial losses. The mural was covered with a layer of dirt and lime powder that had penetrated the reed mats; panels were also damaged by hundreds of nails that were used to attach the mats; additionally, rainwater had leaked through the roof and had caused water stains on the panels. However the pigments had retained their brightness and the composition was graspable both in detail and in the whole.

\section{THE CONCEPTION OF SIMULTANEOUS EXHIBITION OF DISPARATE HISTORICAL STRATA ${ }^{11}$}

A complicated debate evolved around the feasibility of co-existence or preservation of either of the two historical strata. The final decision made by members of the expert panel that included various involved parties

10 TKVA Archive, s.N.9.7000: Rahukohtu tn. 5, 1.6.

11 The conservation and restoration work of the ceiling was carried out by H\&M Restuudio OÜ and by students from the Department of Cultural Heritage and Conservation at the Estonian Academy of Arts, supervised by Hilkka Hiiop and Merike Kallaste. 


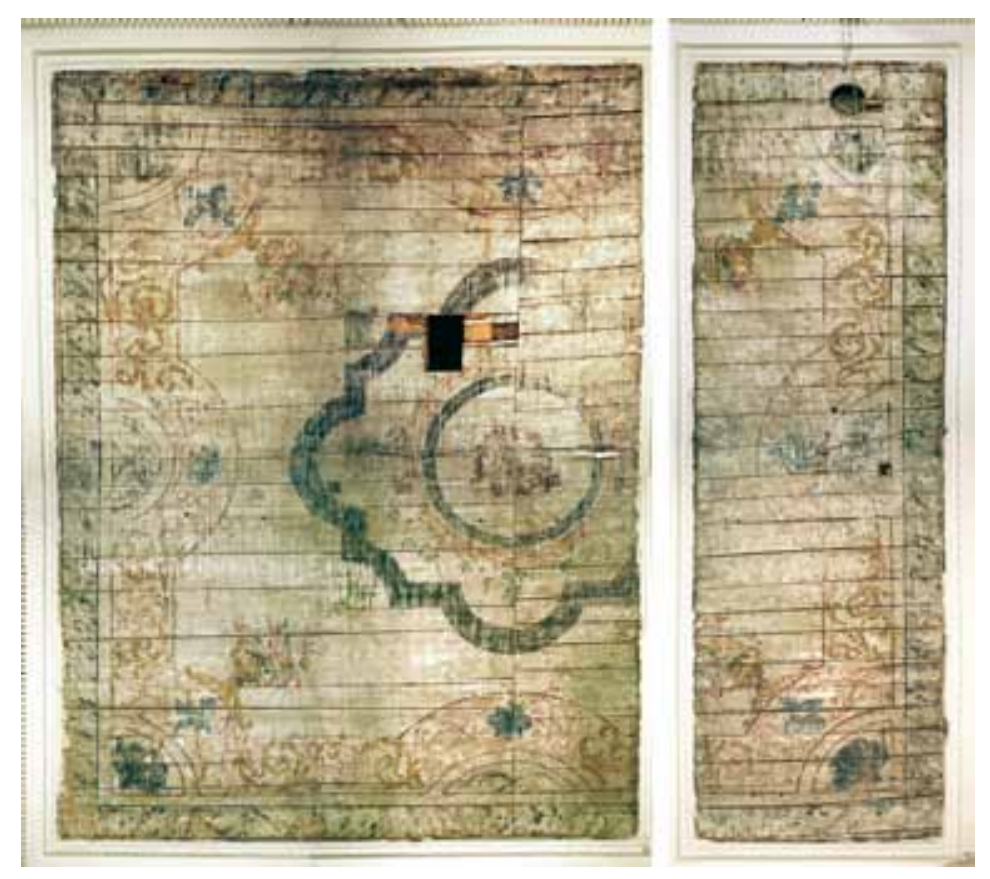

Fig. 1. Rahukohtu 5 ceiling at the time of discovery in 1997. Photo by Peeter Säre
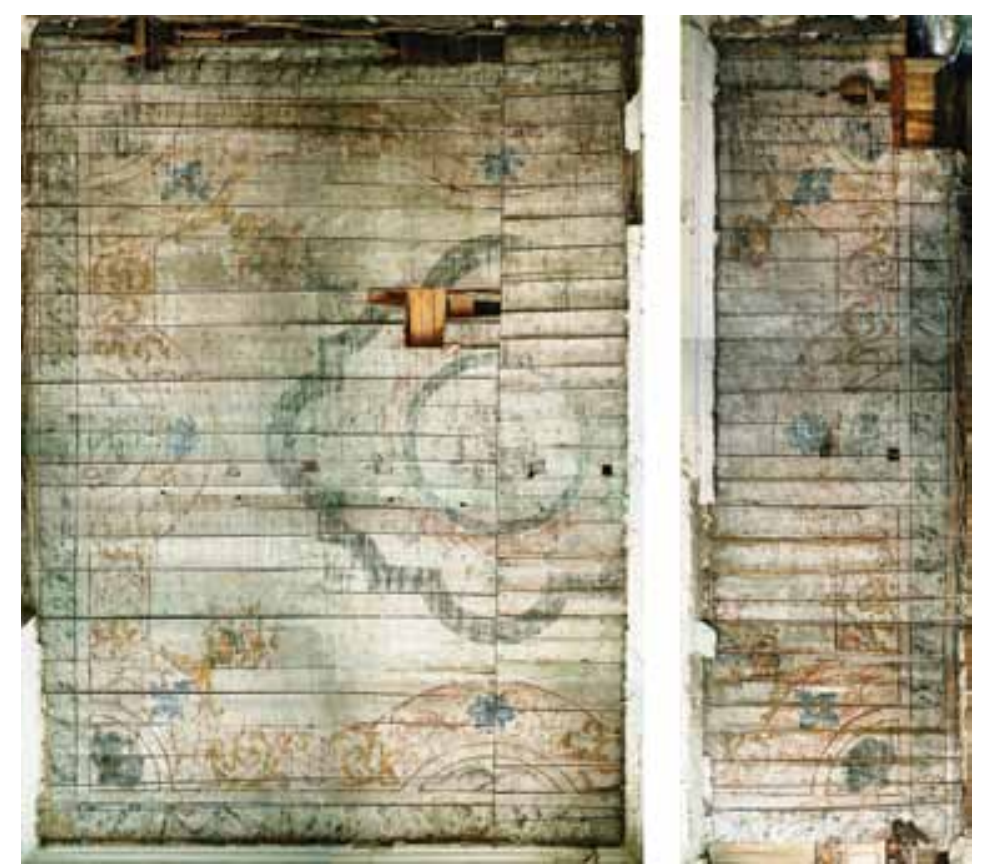

Fig. 2. Rahukohtu 5 ceiling before conservation. Restoration. Photo by Martin Siplane
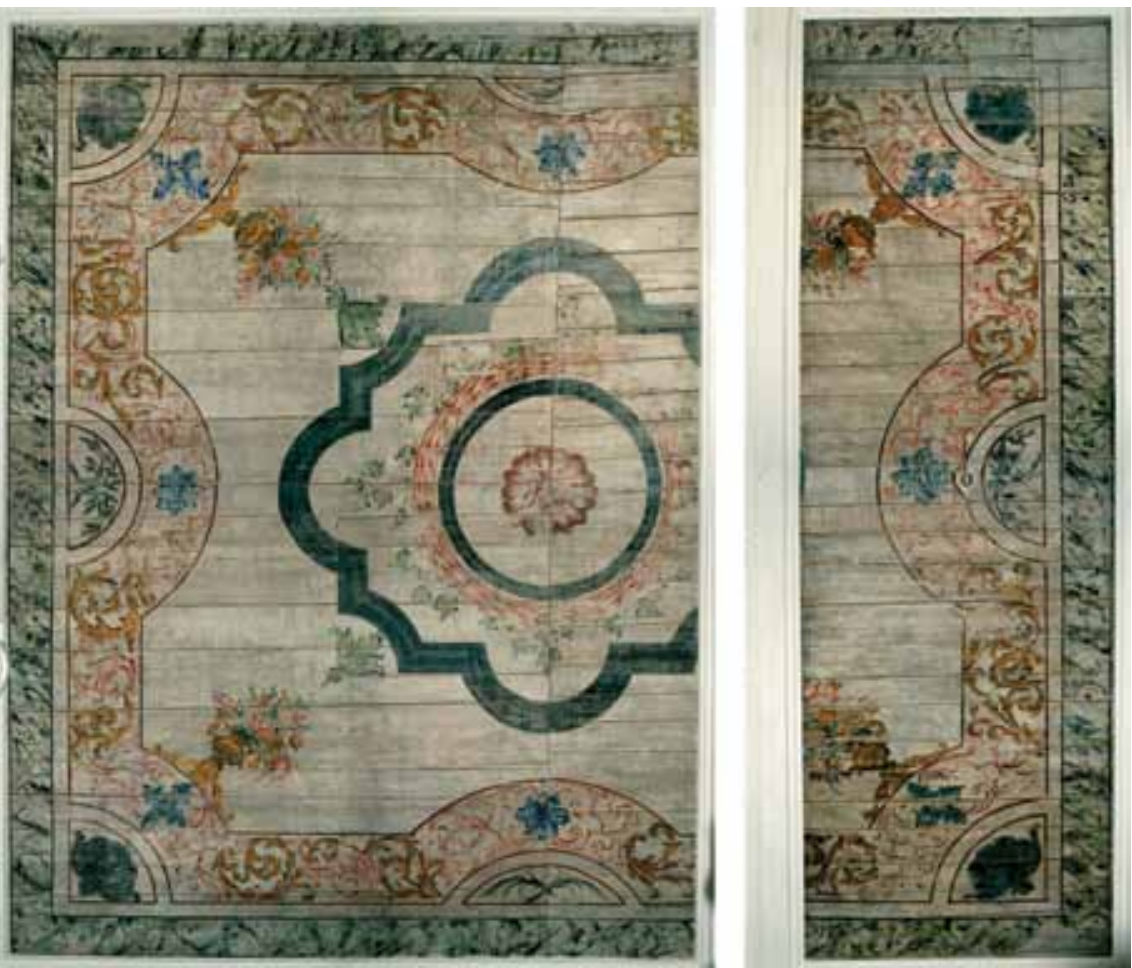

Fig. 3. Rahukohtu 5 ceiling after conservation. Photo Peeter Säre

was to preserve and display both historical layers - the eighteenth century painted ceiling panelling, and the nineteenth century division of space with the exuberant dentil cornice - simultaneously. Promoting the perception of aesthetic composition in its unity, a display area is placed within the dividing wall. Such decision emerged as a compromise between the reality of a historical artefact and contemporary needs of its inhabitants. The final solution won out among all parties and enabled the owner of the estate to open the artistic monument for wider public: the painting can now be

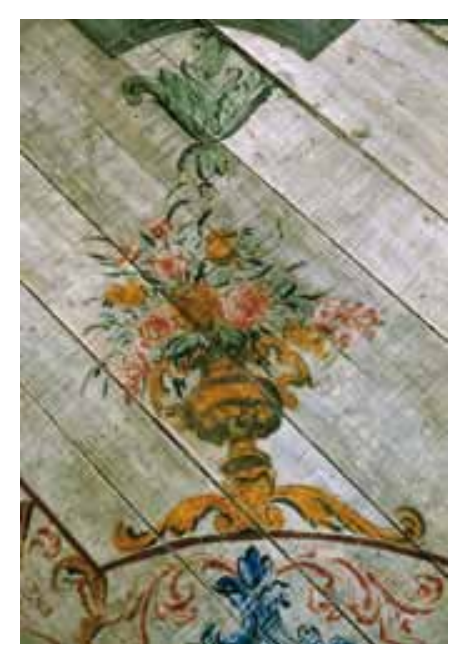

Fig. 4. Rahukohtu 5 ceiling. A detail after conservation. Photo Peeter Säre 
observed through the display window on the staircase without disturbing the privacy of residents.

\section{THE CONSERVATION OF THE MURAL AND ITS SURROUNDING SPACE}

The purpose of the conservation and restoration work was to stabilise the condition of the painted panelling, to clean and consolidate the paint layer, to repair the damage to the wooden structure, and to recreate the aesthetic unity of the artwork through retouching.

The gaps between planks are caulked with tow to keep the filler from falling out through cracks and to join the background surface of the mural. As the ceiling is presumably distempered with binder sensitive to water, the only option is to dry clean the surface of the mural. Because of water sensitivity, synthetic adhesive is used to fix the paint layer -5 percent Paraloid $B 72$ solution in acetone. The areas damaged by microorganisms are treated with biocide; also replacements and repairs are made to the wooden structure.

The retouching of the mural is based on the theory of restoration by Cesare Brandi: for him, the history of artwork and its aesthetic unity are equally valued. ${ }^{12}$ As a guiding principle, substantial losses in painted surface and wood are not reconstructed and maximal amount of original substance in its historical authenticity is retained. Only the geometry of central, architectonic elements of the composition is reconstructed. Small losses in the paint layer are reduced to the background through neutral tone retouching, allowing the viewer to optically recreate the intactness of the mural and in this manner simultaneously perceive the original work and the beauty of history.

In parallel to the conservation of the panelling, the Late Classicist dentil cornice is restored in both rooms ${ }^{13}$ but based on another idea: all missing details are reconstructed using the original as a model. When co-exhibited, a curious synergy appears at the cross-section of two periods in history: the conservated restored ceiling takes on a role of a panel painting and the surrounding exuberant cornice becomes a framing.

12 Cesare Brandi, Theory of Restoration (Firenze: Nardini Editore, 2005), 50

13 The work was carried out by ART-Restauraator.

\section{CONCLUSION}

Plafond paintings are only a fraction of all painted ceilings in the Old Town of Tallinn as these works demand mastery and sense of composition unnecessary when painting patterns on beams. ${ }^{14}$ With this grand and unique ceiling, a significant contribution has been made to the history of Estonian art and the city of Tallinn has obtained another little pearl.

Hilkka Hiiop, Eva Tammekivi: A Newly Conserved Plafond Painting Enriches the Old Town of Tallinn

Keywords: CeIling PAINTING, GLUe-BOUnd PAINTING, PLAFOnd, DENTIL CORNICE, CONSERVATION

SUMmARY:

An exquisite panel muralceiling painting was conserved and restored in the Old Town of Tallinn at the Rahukohtu 5 building on the Patkul viewing platform after more than a decade of exposition to unsatisfactory environmental conditions. This article provides a brief overview of the estate history and its owners, placing the conserved mural within the historical context of ceiling panelling in Tallinn, and addresses the issues of simultaneous exhibition of diverse historical strata and the conception of conserving both the mural and its surrounding space.

CV - HiLkKa HiIop

Hilkka Hiiop (PhD) is the head of Conservation Departement in Art Museum of Estonia as well as being responsible for contemporary art conservation in Kumu Art Museum. She is also assistant professor and coordinator of the artefact conservation branch at the Estonian Academy of Art, Departement of Conservation. She has worked as a conservator of mural paintings in Rome 2003-2009, supervised a number of conservation and technical investigation projects in Estonia, curated exhibitions, and made scientific research on topic of conservation and technical art history. Hiiop's PhD theses (2012) treated the conservation management of contemporary art.

14 Krista Kodres, Tallinlane ja tema maja. Jõuka Tallinna kodaniku elamu ca 1600-1750. Maja, planeering, kaunistused ja sisustus, manuscript for a monography submitted for phD, vol. IA (Tallinn Estonian Academy of Arts, 1999), 193-194. 


\section{CV - Eva TAMmeKivi}

Eva Tammekivi is a graduate student at the Estonian Academy of Arts, Department of Cultural Heritage and Conservation. She received her Bachelor of Arts degree from the Estonian Academy of Arts in 2012 with the thesis titled An Altarpiece Found in the Attic Makes Its Way to the Church: Survey and Conservation of the Altarpiece ,Lord help me!' She has contributed to several studies of interior decoration and has also taken part in conservation and restoration projects including an eighteenth century painted board ceiling in the Old Town of Tallinn, Johann Köler's altarpiece in St Charles Church in Tallinn, and lunette paintings in the Great Guild Hall of Tallinn. 